\title{
Isoniazid-Isatin Hydrazone Derivatives: Synthesis, Antitubercular Activity and Molecular Docking Studies
}

\author{
Mardi Santoso, ${ }^{1, *}$, Muhammad Riza Ghulam Fahmi², \\ Yehezkiel Steven Kurniawan $^{3}$, Taslim Ersam ${ }^{1}$, Sri Fatmawati ${ }^{1}$, \\ Fahimah Martak ${ }^{1}$ and Arif Fadlan ${ }^{1}$ \\ ${ }^{1}$ Department of Chemistry, Institut Teknologi Sepuluh Nopember, East Java 60111, Indonesia \\ ${ }^{2}$ Universitas Ma Chung, East Java 65151, Indonesia \\ ${ }^{3}$ Department of Chemistry, Universitas Gadjah Mada, Yogyakarta 55281, Indonesia
}

("Corresponding author's e-mail: tsv09@chem.its.ac.id)

Received: 18 June 2020, Revised: 12 May 2021, Accepted: 18 May 2021

\begin{abstract}
This study examined the synthesis of isoniazid-isatin hydrazone derivatives 5-7, followed by an investigation on the in vitro antitubercular activity against Mycobacterium tuberculosis $\mathrm{H} 37 \mathrm{Rv}$ and molecular docking. A yield of $81-92 \%$ of these compounds was achieved, with structural characterization by spectroscopic methods (FTIR, NMR, HRMS). The in vitro antitubercular activity was evaluated against $M$. tuberculosis $\mathrm{H} 37 \mathrm{Rv}$, and the highest effect was observed in compound 7, with a minimum inhibitory concentration (MIC) of $0.017 \mathrm{mM}$, lower than rifampicin (MIC $0.048 \mathrm{mM}$ ), which served as the positive control. In addition, the molecular docking of 5-7 was performed to visualize the interaction of isoniazid-isatin hydrazone derivatives with the active site of InhA receptor, which was in agreement with the experimental data. The hydrogen bonding with Ser94 and $\pi-\pi$ interaction with Phe41 and/or Phe97 on the InhA active site was pivotal for the antitubercular activity.
\end{abstract}

Keywords: Antitubercular, Hydrazone, Isatin, Isoniazid, Molecular docking

\section{Introduction}

Tuberculosis (TB) is a severe infectious illness caused by the bacteria Mycobacterium tuberculosis that mostly affects the lungs and is one of the top ten causes of death globally [1-3]. Approximately 10 million individuals throughout the world were infected, with 1.3 million of them dying in 2017 [4]. Rifampicin, isoniazid, ethambutol, and pyrazinamide are the most often used treatments, followed by fluoroquinolones, amikacin, kanamycin, and capreomycin as second-line treatments. [5-7]. Over the last several years, however, drug resistance has been observed [8-11]; therefore, more emphasis is placed on discovery and development.

Molecular hybridization is one of the novel concepts in drug design and discovery, based on the combination of pharmacophore moieties obtained from different bioactive compounds, leading to the formation of a hybrid with higher affinity and efficacy than the parent drugs $[12,13]$. Isatin is an attractive compound in medicinal chemistry, resulting from its wide biological activities, including antitubercular [14,15], antibacterial [16] and anticancer [17]. The structure-activity relationship study of isatin derivatives revealed the formation of 5-halogenation [18-20], $N$-alkylation [21], $N$-Mannich base [22], metal complexation [23], and $\mathrm{N}$-Schiff base [24] are highly effective in increasing biological activity [25]. These characteristics demonstrate the potential for development as an antitubercular agent, as observed with derivatives containing hydrazone group $(-\mathrm{C}=\mathrm{N}-\mathrm{NH}-\mathrm{R})$ [26,27]. Aboul-fadl and co-workers synthesized 5-fluoroisatin isoniazid hydrazone derivatives from isatin and isoniazid with promising activity against $M$. tuberculosis H37Rv (MIC $0.035 \mathrm{mM}$ ) [19], and despite the potential application, only a few studies have been reported [1,28,29]. A previous study indicated 5,7-dibromoisatin based hydrazone derivatives have lower MIC value than parent drugs [30]. Based on these literature studies and interests in isatin hydrazone derivatives, this research aims to synthesize 5,7-dibromoisatin based isoniazid-isatin hydrazone derivatives, followed by the evaluation of in vitro antitubercular activity against $M$. tuberculosis $\mathrm{H} 37 \mathrm{Rv}$, and molecular docking. The last investigation was conducted to identify the interaction between the synthesized compounds and $M$. tuberculosis InhA as the receptor. 


\section{Materials and methods}

All chemicals were purchased from Sigma-Aldrich (St. Louis, MO, USA) or Merck (Merck, Darmstadt, Germany) and used without further purification. The solvents used were of analytical grade (Merck, Darmstadt, Germany, thin layer chromatography (TLC) was performed in silica gel (Kieselgel 60 $\mathrm{F}_{254}, 0.20 \mathrm{~mm}$ Merck, Darmstadt, Germany), and the compounds were detected by UV lamp (245 and 366 $\mathrm{nm})$. The melting points were measured using the Fischer John apparatus (Cole Parmer, Illionis, USA) and uncorrected, while infrared spectra were performed from $\mathrm{KBr}$ disc, using FTIR Shimadzu 8400S (Shimadzu Co., Kyoto, Japan). The ${ }^{1} \mathrm{H}$ NMR (500 MHz) and ${ }^{13} \mathrm{C}$ NMR (126 MHz) spectra were recorded in DMSO- $d_{6}$ on a JEOL JNM-ECA 500 NMR (JEOL Ltd., Tokyo, Japan) and Waters LCT Premier XE instrument (Waters, Hertfordshire, UK) was used for mass spectra analysis.

\section{General procedure for the synthesis of $\mathrm{N}$-alkyl-5,7-dibromoisatins}

5,7-Dibromoisatin 1 was dissolved in DMF (10 mL) and reacted with sodium hydride (2 equivalent) by stirring at room temperature for $10 \mathrm{~min}$. Then benzyl bromide (1 equivalent) was added, and the mixture was stirred for $1 \mathrm{~h}$ at room temperature. After the reaction, the mixture was diluted with cold brine $(10 \mathrm{~mL})$ and then extracted 3 times with dichloromethane $(20 \mathrm{~mL})$. The organic phase was washed 3 times with distilled water $(10 \mathrm{~mL})$ and dried over anhydrous magnesium sulfate. The solvent was removed in vacuo to obtain the $N$-alkyl-5,7-dibromoisatin products [30].

$\mathrm{N}$-Benzyl-5,7-dibromoisatin 2: Reaction between 5,7-dibromoisatin 1 (58 $\mathrm{mg}, 0.19 \mathrm{mmol}$ ) and benzyl bromide $(65 \mathrm{mg}, 0.38 \mathrm{mmol})$ gave compound 2 as a red solid $(71 \mathrm{mg} ; 94 \%)$ m.p. $86-87^{\circ} \mathrm{C}$. FTIR $\left(v_{\max }, \mathrm{cm}^{-1}\right): 3059,2921,1735,1594,1451 .{ }^{1} \mathrm{H}-\mathrm{NMR}$ (DMSO- $\left.d_{6}, 500 \mathrm{MHz}, \mathrm{Si}\left(\mathrm{CH}_{3}\right)_{4}=0 \mathrm{ppm}\right): \delta=5.21$ $\left(\mathrm{s}, 2 \mathrm{H}, \mathrm{CH}_{2}\right), 7.20-7.34(\mathrm{~m}, 5 \mathrm{H}$, benzyl ArH), $7.76(\mathrm{~d}, J=2.0 \mathrm{~Hz}, 1 \mathrm{H}$, isatin $\mathrm{ArH}), 7.96(\mathrm{~d}, J=2.0 \mathrm{~Hz}$, $1 \mathrm{H}$, isatin $\mathrm{ArH}$ ).

N-4-Bromobenzyl-5,7-dibromoisatin 3: Reaction between 5,7-dibromoisatin 1 (46 mg, $0.15 \mathrm{mmol}$ ) and 4-bromobenzyl bromide (38 mg, $0.15 \mathrm{mmol}$ ) gave compound 3 as an orange solid (68 $\mathrm{mg}$; $91 \%$ ). m.p. $156-157{ }^{\circ} \mathrm{C}$. FT-IR $\left(v_{\max }, \mathrm{cm}^{-1}\right): 3016,2921,1738,1598,1439 .{ }^{1} \mathrm{H}-\mathrm{NMR}$ (DMSO- $d_{6}, 500 \mathrm{MHz}$, $\left.\mathrm{Si}\left(\mathrm{CH}_{3}\right)_{4}=0 \mathrm{ppm}\right): \delta=5.16\left(\mathrm{~s}, 2 \mathrm{H}, \mathrm{CH}_{2}\right), 7.33(\mathrm{~d}, 2 \mathrm{H}, J=8.4 \mathrm{~Hz}$, benzyl ArH $), 7.49(\mathrm{~d}, J=8.4 \mathrm{~Hz}, 2 \mathrm{H}$, benzyl ArH), $7.76(\mathrm{~d}, J=2.0 \mathrm{~Hz}, 1 \mathrm{H}$, isatin $\mathrm{ArH}), 7.96(\mathrm{~d}, J=2.0 \mathrm{~Hz}, 1 \mathrm{H}$, isatin ArH).

\section{General procedure for the synthesis of isoniazid-isatin hydrazone derivatives}

A mixture of isoniazid 4 and the corresponding 5,7-dibromoisatin derivatives (2 or 3 ) (0.5 equivalent) was dissolved in ethanol $(30 \mathrm{~mL})$. Then a catalytic amount $(2-3$ drops $)$ of concentrated sulfuric acid was added and the mixture was refluxed for $4 \mathrm{~h}$. After the reaction, the mixture was evaporated at room temperature. The resulting solid was recrystallized from ethanol to give isoniazid hydrazone derivatives 5-7.

2-Isonicotinoylhydrazone-5,7-dibromoisatin 5: Reaction between isoniazid 4 (33 $\mathrm{mg}, 0.24 \mathrm{mmol})$ and isatin 1 (36 mg, $0.12 \mathrm{mmol}$ ) gave compound 5 as a yellow solid (46 mg; $92 \%$ \%). m.p. $310-31{ }^{\circ} \mathrm{C}$. FT-IR $\left(v_{\max }, \mathrm{cm}^{-1}\right): 3439,3164,1690,1513$. HRMS (ESI): $m / z$ for $\mathrm{C}_{14} \mathrm{H}_{7} \mathrm{~N}_{4} \mathrm{O}_{2} \mathrm{Br}_{2}[\mathrm{M}-\mathrm{H}]^{-}$calcd 420.8936, found 420.8946. ${ }^{1} \mathrm{H}-\mathrm{NMR}$ (DMSO- $\left.d_{6}, 500 \mathrm{MHz}, \mathrm{Si}\left(\mathrm{CH}_{3}\right)_{4}=0 \mathrm{ppm}\right): \delta=7.71(\mathrm{~s}, 1 \mathrm{H}, \mathrm{NH}$ isatin), 7.79 (s, 1H, isatin $\mathrm{ArH}), 7.88(\mathrm{~s}, 1 \mathrm{H}$, isatin $\mathrm{ArH}), 8.80(\mathrm{~d}, 2 \mathrm{H}$, pyridine $\mathrm{ArH}), 8.89$ (d, 2H, pyridine $\mathrm{ArH}), 11.84$ (s, $1 \mathrm{H}, \mathrm{NH}$ hydrazide). The sample was not soluble enough for ${ }^{13} \mathrm{C}$ NMR measurement.

2-Isonicotinoylhydrazone-3-(N-benzyl)-5,7-dibromoisatin 6: Reaction between isoniazid 4 (27 $\mathrm{mg}$, $0.2 \mathrm{mmol})$ and $N$-benzyl-5,7-dibromoisatin $2(40 \mathrm{mg}, 0.1 \mathrm{mmol})$ gave compound $\mathbf{6}$ as a dark orange solid (41 mg; $81 \%$ ). m.p. $325-326^{\circ} \mathrm{C}$. FT-IR $\left(v_{\max }, \mathrm{cm}^{-1}\right): 3455,3026,2968,1738,1366$. HRMS (ESI): $\mathrm{m} / z$ for $\mathrm{C}_{21} \mathrm{H}_{15} \mathrm{~N}_{4} \mathrm{O}_{2} \mathrm{Br}_{2}[\mathrm{M}+\mathrm{H}]^{+}$calcd 512.9562, found 512.9573. ${ }^{1} \mathrm{H}-\mathrm{NMR}$ (DMSO-d 6 , $500 \mathrm{MHz}, \mathrm{Si}\left(\mathrm{CH}_{3}\right)_{4}=0$ ppm): $\delta=5.32\left(\mathrm{~s}, 2 \mathrm{H}, \mathrm{CH}_{2}\right), 7.23-7.30(\mathrm{~m}, 4 \mathrm{H}$, pyridine $\mathrm{ArH}), 7.78(\mathrm{~s}, 1 \mathrm{H}, \mathrm{NH}), 7.83(\mathrm{~d}, 2 \mathrm{H}$, isatin ArH), 8.87 (s, 5H, ArH). The sample was not soluble enough for ${ }^{13} \mathrm{C}$ NMR measurement.

2-Isonicotinoylhydrazone-3-(N-4-bromobenzyl)-5,7-dibromoisatin 7: Reaction between isoniazid 4 (23 mg, $0.017 \mathrm{mmol}$ ) and $N$-4-bromobenzyl-5,7-dibromoisatin 3 (40 mg, $0.0085 \mathrm{mmol}$ ) gave compound 7 as an orange solid (42 mg; 84 \%). m.p. $227-228^{\circ} \mathrm{C}$. FT-IR $\left(v_{\max }, \mathrm{cm}^{-1}\right): 3249,3063,2818,1692,1487$, 1738, 1366. HRMS (ESI): $m / z$ for $\mathrm{C}_{21} \mathrm{H}_{14} \mathrm{~N}_{4} \mathrm{O}_{2} \mathrm{Br}_{3}[\mathrm{M}+\mathrm{H}]^{+}$calcd 590.8667, found 590.8664. ${ }^{1} \mathrm{H}-\mathrm{NMR}$ (DMSO- $\left.d_{6}, 500 \mathrm{MHz}, \mathrm{Si}\left(\mathrm{CH}_{3}\right)_{4}=0 \mathrm{ppm}\right): \delta=5.28\left(\mathrm{~s}, 2 \mathrm{H}, \mathrm{CH}_{2}\right), 7.24(\mathrm{~d}, \mathrm{~J}=\mathrm{Hz}, 7.47(\mathrm{~d}, 1 \mathrm{H}$, isatin ArH), $7.76-7.82\left(\mathrm{~m}, 6 \mathrm{H}\right.$, isatin ArH \& benzyl ArH), $8.78-8.85\left(\mathrm{~m}, 4 \mathrm{H}\right.$, pyridine ArH). ${ }^{13} \mathrm{C}-\mathrm{NMR}\left(\mathrm{DMSO}-d_{6}\right.$, $\left.125 \mathrm{MHz}, \mathrm{DMSO}-d_{6},=39.5 \mathrm{ppm}\right): \delta=44.0,104.4,116.5,120.9,122.0,123.2,124.9,129.1,131.9,136.7$, $138.6,139.0,139.6,139.8,150.8,151.2,162.0,164.9$. 


\section{Antitubercular assay against $M$. tuberculosis $\mathbf{H}_{37} \mathbf{R v}$}

The in vitro antitubercular activity of isoniazid-isatin hydrazone derivatives was evaluated against M. tuberculosis H37Rv (ATCC25618). The solid dilution method was used to determine the minimum inhibitory concentration (MIC) value of the synthesized compounds, according to the previously described procedure [16,31]. The M. tuberculosis $\mathrm{H} 37 \mathrm{Rv}$ was briefly cultured at $10^{8} \mathrm{CFU} / \mathrm{mL}$ concentration by dropping 1 dose into a screw-capped tube containing 10 glass beads, 2 drops of $0.05 \%$ vol/vol Tween, and distilled water. Subsequently, $0.8 \mathrm{~mL}$ of the solution was added to $80 \mathrm{~mL}$ Middle Brook Double Strength (MBDS) media to formulate a $10^{6} \mathrm{CFU} / \mathrm{mL}$ concentration of the bacteria. The isoniazid-isatin hydrazones 5-7 were dissolved in the stock solution of DMSO $(10,000 \mu \mathrm{g} / \mathrm{mL})$, which was subsequently diluted to 100,10 , and $1 \mu \mathrm{g} / \mathrm{mL}$. In addition, rifampicin was used as the positive control, while $20 \% \mathrm{v} / \mathrm{v}$ DMSO in distilled water was used as the negative control. These were all introduced into the Lowenstein Jensen (LJ) media, followed by the inoculation of samples and incubation for 4 weeks at $37{ }^{\circ} \mathrm{C}$. Next, in vitro assay was performed in 3 replications and the reported MIC values were determined as the average of 3 evaluations.

\section{Molecular docking study}

The geometry optimization of the ligands was performed using DFT/B3LYP/6-31 G (d,p) on Orca 4.1. A 2-trans-enoyl-acyl-carrier protein reductase InhA of $M$. tuberculosis (PDB ID: 4DRE) was downloaded from https:/www.rcsb.org/ and was prepared using UCSF Chimera 13.1 and AutoDock Tools. 1.5.6. The docking study was conducted on autodock4 using the Lamarckian Genetic Algorithm for searching the preferred docking pose (Number of LGA runs: 100). The ligands were docked on the same site as the native ligand (NADH) with a grid box of size 50 . The results were visualized using AutoDock Tools and Discovery Studio Visualizer.

\section{Results and discussion}

Synthesis of isoniazid-isatin hydrazone derivatives

Figure 1 shows the synthesis scheme of the novel isoniazid-isatin hydrazone derivatives 5-7, which involved 2 steps, comprising the $N$-alkylation of isatin 1 and the subsequent imine formation between 5,7dibromoisatin 1-3 and isoniazid 4. In addition, several methods have been reported for the alkylation process [24,25] and this study involved the use of $\mathrm{NaH}$ as a base in DMF. Subsequently, the use of benzyl bromide and 4-bromobenzyl bromide led to the formation of $N$-benzyl-5,7-dibromoisatin 2 and $N$-4bromobenzyl-5,7-dibromoisatin 3, with 94 and $91 \%$ yield, respectively. Both structures were determined through spectroscopic methods. The ${ }^{1} \mathrm{H}-\mathrm{NMR}$ spectra of $\mathbf{2}$ and $\mathbf{3}$ showed the proton signals of methylene groups of benzyl substituent at 5.20 and $5.15 \mathrm{ppm}$, alongside the peaks of benzyl bromide aromatic protons observed at $7.28-7.44 \mathrm{ppm}$. Further, the isatin-isoniazid hydrazone derivatives 5, 6, and 7 were obtained, by coupling of 1-3 and isoniazid 4 in ethanol in the presence of sulfuric acid, and a yield of 92 , 81 and $84 \%$ were respectively obtained. The ${ }^{1} \mathrm{H}$ NMR spectrum of 5-7 showed the aromatic protons of isoniazid at $8.80-8.89 \mathrm{ppm}, 7.23-7.30 \mathrm{ppm}$, and $8.75-8.85 \mathrm{ppm}$, respectively, while the mass spectra were agreed properly, with the calculated $\mathrm{m} / \mathrm{z}$ of the synthesized compounds, which confirm successful synthesis. 
<smiles>O=C1Nc2c(Br)cc(Br)cc2C1=O</smiles>

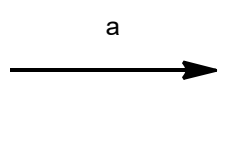

1<smiles>[R]N1C(=O)C(=O)c2cc(Br)cc(Br)c21</smiles>

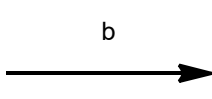

$1 \mathrm{R}=\mathrm{H}$

$2 \mathrm{R}=\mathrm{CH}_{2} \mathrm{Ph}$

$3 \mathrm{R}=\mathrm{CH}_{2} \mathrm{Ph}-4-\mathrm{Br}$<smiles>[R]N1C(=O)C(=O)c2cc(Br)cc(Br)c21</smiles>

$2 \mathrm{R}=\mathrm{CH}_{2} \mathrm{Ph}$

$3 \mathrm{R}=\mathrm{CH}_{2} \mathrm{Ph}-4-\mathrm{Br}$<smiles>[R]N1C(=O)/C(=N\NC(=O)c2ccncc2)c2cc(Br)cc(Br)c21</smiles>

$5 \mathrm{R}=\mathrm{H}$

$6 \mathrm{R}=\mathrm{CH}_{2} \mathrm{Ph}$

$7 \mathrm{R}=\mathrm{CH}_{2} \mathrm{Ph}-4-\mathrm{Br}$

Figure 1 Synthesis of 5-7. Reagents/conditions: (a) $\mathrm{NaH}$ (2 eq), DMF (0.02 M), rt $1 \mathrm{~h}, \mathrm{BnBr}$ or 4-Br$\mathrm{BnBr}(1 \mathrm{eq}), 2$ (91 \%), 3 (91 \%); (b) isoniazid (4, 2 eq), EtOH (0.003 M), $\mathrm{H}_{2} \mathrm{SO}_{4}$ c (cat.), reflux 4 h, 5 (92 $\%), 6(81 \%), 7(84 \%)$.

\section{Antitubercular activity}

The in vitro antitubercular activity of compounds 5-7 was evaluated against the $M$. tuberculosis H37Rv strain, using the solid dilution method. Table 1 shows the MIC values for all products, including the positive control, rifampicin. Specifically, compound 7 demonstrated the highest antitubercular activity at a MIC value of $0.017 \mathrm{mM}$, which was lower than rifampicin, and other previously reported compounds $[19,20]$. This result showed the importance of Bromo substituents in the activity of isoniazid-isatin hydrazone derivatives $M$. tuberculosis $\mathrm{H} 37 \mathrm{Rv}$, hence molecular docking was subsequently conducted to understand the phenomenon.

Table 1 MIC value of isoniazid derivatives against M. tuberculosis $\mathrm{H}_{37} \mathrm{Rv}$.

\begin{tabular}{cc}
\hline Compound & MIC (mM) \\
\hline $\mathbf{5}$ & 0.237 \\
$\mathbf{6}$ & 0.195 \\
$\mathbf{7}$ & 0.017 \\
Positive control $^{\mathrm{a}}$ & 0.048 \\
Negative control $^{\mathrm{b}}$ & 0.000 \\
\hline
\end{tabular}

${ }^{a}$ Rifampicin was used as the positive control

b $20 \% \mathrm{vol} / \mathrm{vol}$ DMSO was used as the negative control

\section{Molecular docking study}

Molecular docking was conducted to predict and visualize the intermolecular interaction between compounds 5-7 and the active site of a 2-trans-enoyl-acyl carrier protein reductase InhA of $M$. tuberculosis, and a similar location with $\mathrm{NADH}$ as the native ligand was identified. The results demonstrated the occurrence of interactions through hydrogen bonding, $\pi-\pi$, or dipole-dipole (Table 2 , Figure 2). Specifically, the interaction of compound 5 was established through hydrogen bonding with Val65, Ser20, Ser94, Ile95 and Gly96, $\pi-\pi$ stacking with Phe41, and dipole-dipole between Leu63 and the Bromo substituent. In addition, a similar mode was shown by compound $\mathbf{6}$, which occurred through hydrogen bonding with Thr39, Ser94, Gly14 and Gly96, and $\pi-\pi$ stacking with Phe41 and Phe97. Meanwhile, compound 7 relates with the active site via hydrogen bonding with Thr39, Ser94, Gly14, and 
Gly96, $\pi-\pi$ stacking with Phe41 and Phe97, and dipole-dipole interaction between Gly40 and Bromo substituent.

Table 2 Molecular docking results of compound 5-7 using InhA as the receptor.

\begin{tabular}{|c|c|c|c|}
\hline Compound & 5 & 6 & 7 \\
\hline $\begin{array}{c}\text { Binding free } \\
\text { Energy }\left(\mathrm{kcal} \mathrm{mol}^{-1}\right)\end{array}$ & -8.89 & -10.31 & -10.61 \\
\hline $\begin{array}{c}\text { Inhibition } \\
\text { Constant (nM) }\end{array}$ & 306.35 & 27.87 & 16.60 \\
\hline Interaction & $\begin{array}{c}\text { H-Bond: } \\
\text { Val65, Ser20, Ser94, } \\
\text { Ile95, Gly96 } \\
\pi-\pi: \text { Phe41 } \\
\text { Halogen: Leu63 }\end{array}$ & $\begin{array}{c}\text { H-Bond: } \\
\text { Thr39, Ser94, } \\
\text { Gly14, Gly96 } \\
\pi-\pi: \text { Phe41, Phe97 }\end{array}$ & $\begin{array}{c}\text { H-Bond: } \\
\text { Thr39, Ser94, } \\
\text { Gly14, Gly96 } \\
\pi-\pi: \text { Phe41, Phe97 } \\
\text { Halogen: Gly40 }\end{array}$ \\
\hline
\end{tabular}

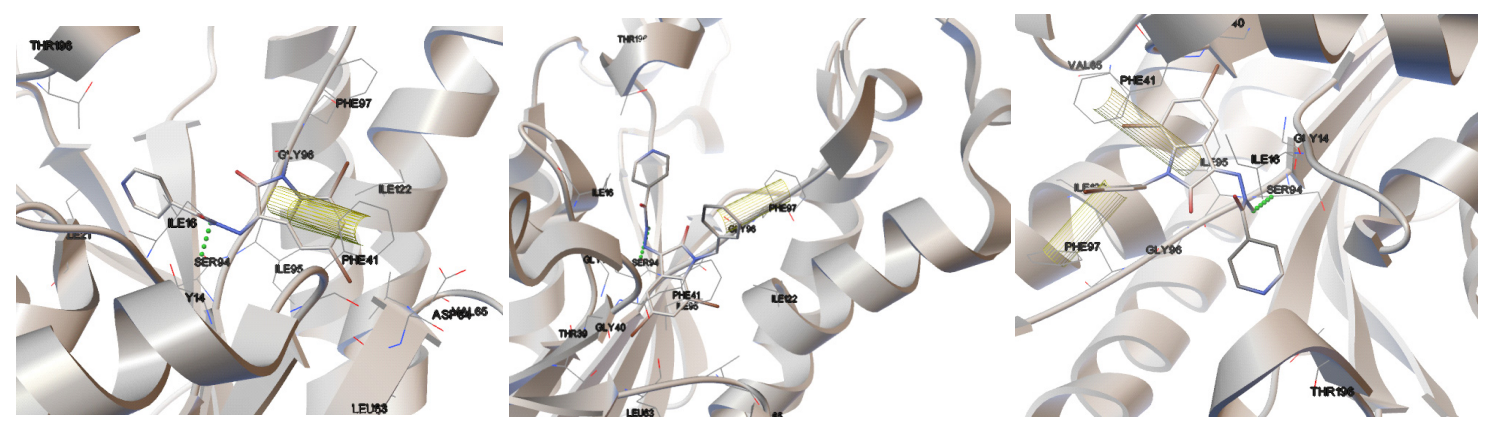

Figure 2 3D visualization of 5-7 (left, center, right) with InhA (PDB ID: 4DRE). The green dashed lines represent the hydrogen bonds.

Wang and co-workers reported the key interaction mechanism for the antitubercular activity of pyrrolo[1,2-a]quinoxaline to occur as the incidence of hydrogen bonding between the - $\mathrm{NH}$ of compounds and $-\mathrm{COO}^{-}$of Ser94, and also the $\pi-\pi$ relationship between the intrinsic aromatic moieties and aromatic residue of Phe41 [34]. Stratan and co-workers also reported the hydrogen bonding between the -NH of compounds and - $\mathrm{COO}^{-}$of Ser94 as the key interaction mechanism for the antitubercular activity of 2phenethylbenzoyl thiourea derivatives [35]. Thomas and Harindran reported the presence of $\pi-\pi$ bonding between the aromatic moieties of isoniazid-containing thiazolidine-4-one derivatives and aromatic residue of Phe41 as crucial for effectiveness [36]. These molecular docking results were in line with previous reports [34-36], which identified hydrogen bonding with Ser94 and $\pi-\pi$ interaction with Phe41 and/or Phe97 as the main mechanism used to form interrelationships, as shown in Figure 2. Also, the most potent antitubercular agent was recognized as compound 7, due to the presence of hydrogen bonding with Ser94, $\pi-\pi$ interaction with Phe41, and between Phe97 and the active site of InhA. This fact relates with the lowest MIC value of $7(0.017 \mathrm{mM})$ observed during in vitro assay, which the $-\mathrm{NH}$ proton of isoniazid and aromatic moieties of isatin and 4-bromobenzyl were critical for antitubercular activity against $M$. tuberculosis $\mathrm{H} 37 \mathrm{Rv}$. In addition, it is possible to describe the effects of the synthesized compounds using binding free energy and inhibition constant parameters, as lower values led to lower inhibition constant, and the subsequent reduction in MIC values. The lowest binding free energy $\left(-10.61 \mathrm{kcal} \mathrm{mol}^{-1}\right)$ and inhibition constant $(16.60 \mathrm{nM})$ were recorded in 7, compared to 5 and $\mathbf{6}$. These findings confirm the presence of an alignment between the results for molecular docking and the in vitro assay. 


\section{Conclusions}

The isoniazid-isatin hydrazone derivative 5-7 was synthesized effectively and exhibited moderate to high activity against M. tuberculosis H37Rv. With a MIC value of $0.017 \mathrm{mM}$, compound 7 was shown to be the most effective. This was supported by molecular docking findings, which demonstrated that the hydrogen bonding with Ser94 and the $\pi-\pi$ interaction with Phe41 and/or Phe97 are important for antitubercular activity in all samples. Therefore, the findings are valuable for rationalized drug design and development in related fields.

\section{Acknowledgements}

The authors are grateful to Institut Teknologi Sepuluh Nopember (ITS) for the financial support under Penelitian Thesis Magister 2018.

\section{References}

[1] T Aboul-Fadl, FAH Mohammed and EAS Hassan. Synthesis, antitubercular activity and pharmacokinetic studies of some Schiff bases derived from 1-alkylisatin and isonicotinic acid hydrazide (INH). Arch. Pharm. Res. 2003; 26, 778-84.

[2] YQ Hu, S Zhang, F Zhao, C Gao, LS Feng, ZS Lv, Z Xu and X Wu. Isoniazid derivatives and their anti-tubercular activity. Eur. J. Med. Chem. 2017; 133, 255-67.

[3] PFM Oliveira, B Guidetti, A Chamayou, C Andre-Barres, J Madacki, J Kordulakova, G Mori, BS Orena, LR Chiarelli, MR Pasca, C Lherbet, C Carayon, S Massou, M Baron and M Baltas. Mechanochemical synthesis and biological evaluation of novel isoniazid derivatives with potent antitubercular activity. Molecules 2017; 22, 1457.

[4] World Health Organization, Global Tuberculosis Report 2019, Available at: https: / / apps. who. int/ iris/ bitstream/ handle/ 10665/ 329368/ 9789241565714-eng. pdf, accessed December 2019.

[5] D Jiang, GQ Wang, X Liu, Z Zhang, LS Feng and ML Liu. Isatin derivatives with potential antitubercular activities. J. Heterocycl. Chem. 2018; 55, 1263-79.

[6] MA Elhakeem, AT Taher and SM Abuel-Maaty. Synthesis and anti-mycobacterial evaluation of some new isonicotinylhydrazide analogues. Bull. Facul. Pharm. Cairo Univ. 2015; 53, 45-52.

[7] A Atta, S Fahmy, O Rizk, D Sriram, MA Mahran and IM Labouta. Structure-based design of some isonicotinic acid hydrazide analogues as potential antitubercular agents. Bioorg.Chem. 2018; 80, 721-32.

[8] D Zhang, Y Lin, X Chen, W Zhao, D Chen, M Gao, Q Wang, B Wang, H Huang, Y Lu and Y Lu. Docking- and pharmacophore-based virtual screening for the identification of novel Mycobacterium tuberculosis protein tyrosine phosphatase B (MptpB) inhibitor with a thiobarbiturate scaffold. Bioorg. Chem. 2019; 85, 229-39.

[9] PS Salve, SG Alegaon and D Sriram. Three-component, one-pot synthesis of anthranilamide Schiff bases bearing 4-aminoquinoline moiety as Mycobacterium tuberculosis gyrase inhibitors. Bioorg. Med. Chem. Lett. 2017; 27, 1859-66.

[10] SM Kishk, KJ McLean, S Sood, MA Helal, MS Gomaa, I Salama, SM Mostafa, LPSD Carvalho, AW Munro and C Simons. Synthesis and biological evaluation of novel cYY analogues targeting Mycobacterium tuberculosis CYP121A1. Bioorg. Med. Chem. 2019; 27, 1546-61.

[11] OG Shaaban, DAE Issa, AA El-Tombary, SMAE Wahab, AEA Wahab and IA Abdelwahab. Synthesis and molecular docking study of some 3,4-dihydrothieno[2,3-d]pyrimidine derivatives as potential antimicrobial agents. Bioorg. Chem. 2019; 88, 102934.

[12] Z Xu, S Zhang, C Gao, J Fan, F Zhao, ZS Lv and LS Feng. Isatin hybrids and their anti-tuberculosis activity. Chin. Chem. Lett. 2017; 28, 159-67.

[13] T Wang, Y Tang, Y Yang, Q An, Z Sang, T Yang, P Lium T Zhang, Y Deng and Y Luo. Discovery of novel anti-tuberculosis agents with pyrrolo[1,2-a]quinoxaline-based scaffold. Bioorg. Med. Chem. Lett. 2018; 28, 2084-90.

[14] K Han, Y Zhou, F Liu, Q Guo, P Wang, Y Yang, B Song, W Liu, Q Yao, Y Teng and P Yu. Design, synthesis and in vitro cytotoxicity evaluation of 5-(2-carboxyethenyl)isatin derivatives as anticancer agents. Bioorg. Med. Chem. Lett. 2014; 24, 591-4.

[15] Y Xu, J Guan, Z Xu and $\mathrm{S}$ Zhao. Design, synthesis and in vitro anti-mycobacterial activities of homonuclear and heteronuclear bis-isatin derivatives. Fitoterapia 2018; 127, 383-6. 
[16] A Saxena, S Sharma and A Husain. Antimicrobial and anti-tubercular activity of some new indole derivatives. World J. Pharm. Sci. 2015; 3, 1877-82.

[17] S Ke, L Shi and Z Yang. Discovery of novel isatin-dehydroepiandrosterone conjugates as potential anticancer agents. Bioorg. Med. Chem. Lett. 2015; 25, 4628-31.

[18] V Eggadi, U Kulandaivelu, SBB Sheshagiri and VR Jupalli. Evaluation of antioxidant, antimicrobial and anticancer activity of thiazole tagged isatin hydrazones. J. Pharmaceut. Chem. 2016; 3, 4-9.

[19] T Aboul-Fadl, MK Abdel-Hamid and AF Youssef. Schiff bases of indoline-2,3-dione (isatin) derivatives as efficient agents against resistant strains of Mycobacterium tuberculosis. Der Pharma Chemica 2015; 7, 217-25.

[20] WM Eldehna, M Fares, MM Abdel-Aziz and HA Abdel-Aziz. Design, synthesis and antitubercular activity of certain nicotinic acid hydrazides. Molecules 2015; 20, 8800-15.

[21] SB Kumar, M Ravinder, G Kishore, VJ Rao, P Yogeeswari and D Sriram. Synthesis, antitubercular and anticancer activity of new Baylis-Hillman adduct-derived N-cinnamyl-substituted isatin derivatives. Med. Chem. Res. 2014; 23, 1934-40.

[22] UK Singh, SN Pandeya, A Singh, BK Srivastava and M Pandey. Synthesis and antimicrobial activity of Schiff's and N-Mannich bases of isatin and its derivatives with 4-amino-Ncarbamimidoyl benzene sulfonamide. Int. J. Pharmaceut. Sci. Drug Res. 2010; 2, 151-4.

[23] SS Swathy, RS Joseyphus, VP Nisha, N Subhadrambika and K Mohanan. Synthesis, spectroscopic investigation and antimicrobial activities of some transition metal complexes of a [(2-hydroxyacetophenone)-3-isatin]-bishydrazone. Arab. J. Chem. 2016; 9, S1847-S1857.

[24] T Aboul-Fadl, FAS Bin-Jubair and O Aboul-Wafa. Schiff bases of indoline-2,3-dione (isatin) derivatives and nalidixic acid carbohydrazide, synthesis, antitubercular activity and pharmacophoric model building. Eur. J. Med.Chem. 2010; 45, 4578-86.

[25] KHME Tehrani, M Hashemi, M Hassan, F Kobarfard and S Mohebbi. Synthesis and antibacterial activity of Schiff bases of 5-substituted isatins. Chin. Chem. Lett. 2016; 27, 221-5.

[26] P Pakravan, S Kashanian, MM Khodaei and FJ Harding. Biochemical and pharmacological characterization of isatin and its derivatives: From structure to activity. Pharmacol. Rep. 2013; 65, 313-35.

[27] L Yurttaş, M Ertaş, MY Cankılıç and Ş Demirayak. Synthesis and antimycobacterial activity evaluation of isatin-derived 3- [(4-aryl-2-thiazolyl])hydrazone]-1H-indol-2,3-diones. Acta Pharm. Sci. 2017; 55, 51-8.

[28] T Aboul-Fadl and FAS Bin-Jubair. Anti-tubercular activity of isatin derivatives. Int. J. Res. Pharmaceut. Sci. 2010; 1, 113-26.

[29] WM El-Sayed, T Aboul-Fadl and MR Franklin. Effects of isatin-isoniazid derivatives on drug metabolizing and chemoprotective enzymes in mice. Drug Dev. Res. 2010; 71, 313-22.

[30] MRG Fahmi, L Khumaidah, TK Ilmiah, A Fadlan and M Santoso. 2-Thiophenecarboxylic acid hydrazide derivatives: synthesis and anti-tuberculosis studies. IOP Conf. Ser. Mater. Sci. Eng. 2018; 349, 012039.

[31] E Pahlavani, H Kargar and NS Rad. A study on antitubercular and antimicrobial activity of isoniazid derivative. Zahedan J. Res. Med. Sci. 2015; 17, e1010.

[32] SE Adeniji, S Uba and A Uzairu. Quantitative structure-activity relationship and molecular docking of 4-alkoxy-cinnamic analogues as anti-mycobacterium tuberculosis. J. King Saud Univ. Sci. 2020; 32, 67-74.

[33] SE Adeniji, S Uba and A Uzairu. Theoretical modeling for predicting the activities of some active compounds as potent inhibitors against Mycobacterium tuberculosis using GFA-MLR approach. $J$. King Saud Univ. Sci. 2020; 32, 575-86.

[34] R Wang, X Yin, Y Zhang and W Yan. Design, synthesis and antimicrobial evaluation of propylenetethered ciprofloxacin-isatin hybrids. Eur. J. Med.Chem. 2018; 156, 580-6.

[35] E Stratan, N Țurcan, V Crudu, E Romancenco, T Cotelea, GM Niţulescu, C Chiriţă and L Moruşciag. Biological evaluation of new 2-phenethylbenzoyl thiourea derivatives as antituberculosis agents. Farmac. 2018; 66, 97-106.

[36] B Thomas and J Harindran. Design, Synthesis and evaluation of antitubercular activity of Mannich bases of isoniazid-containing thiazolidin-4-one rings. Res. Rev. J. Pharmaceut. Sci. 2016; 7, 1-12. 